\title{
Boris Asafyev's Intonatsiya and German Folk Song in the German Democratic Republic
}

\author{
ANICIA TIMBERLAKE
}

\begin{abstract}
This article examines how East German scholars and teachers understood Boris Asafyev's notion of intonatsiya. It argues that GDR musical discourse and pedagogical practice appropriated the concept to serve German nationalist ends. After offering an overview of the complex meanings the famously ambiguous idea took on in its East German reincarnation, the article shows that one of the simplest meanings of intonatsiya - a vocabulary of melodic "turns" characteristic of a national style—became its dominant meaning. That meaning was eventually put in practice as a concept underlying new approaches to children's music education. In this new pedagogy, children were to be taught music via learning a vocabulary of representative intonatsiyas. This elementary education, however, was also an education in Romantic-tinged chauvinism, as tonal music was presented as both German and universal.
\end{abstract}

Art reflects the social relations that were in place at the time of its creation. About this Marxist truism, at least, East German musicologists agreed. The debates started when it came to how music in particular should reflect history: how, and where, the facts of the past took audible shape. East German musicologists spent the 1950s, the first decade of the German Democratic Republic's existence, recasting a familiar idealist history of music in sociological terms. Following Lenin's "reflection theory"-the notion that art reflected historical reality-musical styles were traced to social relations and the attitudes that composers held towards them. ${ }^{1}$ For instance, the two contrasting themes of sonata form reflected a growing general consciousness of the social contradictions of the late eighteenth century. ${ }^{2}$ However, reflection theory only stated that music reflected history: it offered no methodology for studying this phenomenon in an academically rigorous manner. For that, East German musicologists turned to the Russian-Soviet musicologist Boris Asafyev's concept of intonatsiya.

Originally put forth by Asafyev in Musical Form as Process (1930), the theory of intonatsiya offered musicologists a way to understand how music communicated genuine emotional and historical content. ${ }^{3}$ In essence-and what follows will be the broadest thinkable version of the contested ideaAsafyev proposed that the emotionally expressive capacities of language derived from speech intonation: rising and falling pitch, as well as shifting pace, volume, and speech rhythm. These

\footnotetext{
${ }^{1}$ Though Elaine Kelly points out that East German cultural policy was heavily influenced by György Lukács's theory of reflection, the East German scholarship discussed here more frequently invoked Lenin's version of the theory. Elaine Kelly, Composing the Canon in the German Democratic Republic: Narratives of Nineteenth-Century Music (New York: Oxford University Press, 2014), https://doi.org/10.1093/acprof:oso/9780199998098.001.0001.

${ }^{2}$ Georg Knepler, "Zur Frage der Widerspiegelung der Wirklichkeit in Beethovens Musik" [On the Question of the Reflection of Reality in Beethoven's Music], Musik und Gesellschaft 2, no. 3 (March 1952): 68.

${ }^{3}$ Boris Vladimirovich Asafyev, Muzïkal'naya forma kak protsess (Leningrad: Muzika, 1930). A revised and expanded version of this book, which contained a new second section entitled Intonatsiya, was published in 1947.
}

Music E Politics 14, Number 2 (Summer 2020), ISSN 1938-7687.

Article DOI: http://dx.doi.org/10.3998/mp.9460447.0014.206 
communicated the emotional content of the speech and/or the emotional state of the speaker, allowing the speaker to express herself and the listener to apprehend her meaning. Music's expressive power similarly relied on patterns of rising and falling pitch, as well as on other music parameters such as timbre, harmony, and rhythm. The term "intonatsiya" was used both to refer to the concept itself and to specific units of musical meaning. Intonatsiyas could be as small as an interval or as broad as the mood of an entire movement. However, not every musical gesture was an intonatsiya: intonatsiyas had to be legible in their environment. As James Tull summarized: "An intonation [he uses the English cognate] ... is a particular musical relationship which has a much more universal application: thus, it may be characteristic of an entire group of compositions or of composers, the musical composition of an entire country, or even that of an entire historical epoch." ${ }^{4}$

However, Musical Form as Process was not published in German translation until 1976. ${ }^{5}$ And thus East German scholars writing about the topic in the 1950s and 1960s used translated scholarship on Asafyev by Polish, Czech, and Russian musicologists. These texts were the foundation of a discourse about intonatsiya that, at a distance from its source texts, would eventually come to reflect concerns distinct to German socialism. ${ }^{6}$ By the time Asafyev's works arrived on the scene, a unique understanding of the term had already become entrenched in both musicology and music pedagogy.

In GDR scholarship, intonatsiya's initial promise-to provide a method for understanding expressive content-was never brought to fruition. However, as I will show, this promise was ultimately taken up in pedagogy. Also left behind were many of the contradictions famously a part of Asafyev's version of the idea. Instead, the term came to refer to a "vocabulary" of characteristic melodic turns believed to define German music. I argue that this understanding of intonatsiya served a number of functions in East German musical life. On the one hand, the study of intonatsiya helped scholars claim that East German musicology was aligned with an international Marxist standard, thus fulfilling a mandate to move the discipline beyond "hermeneutics." (That their understanding of the term was not consistent with that in other countries did not come up until Asafyev's translated text was published.) On the other hand, intonatsiya established an academic foundation for an essentially conservative vision of the German tradition based around the standard seventeenth- through nineteenth-century canon of works. Scholars could now prove familiar and beloved repertoire to be "German" with the confidence of Marxist science.

I am not trying to argue that East Germans missed the true point of Asafyev's theory, or that intonatsiya became somehow distorted, or corrupted, because East German scholarship lacked access to Asafyev's own words. Rather, I am arguing that intonatsiya became a separate, equally legitimate

\footnotetext{
${ }^{4}$ James Robert Tull and B. V. Asaf'ev, “B. V. Asaf'ev's Musical Form as a Process: Translation and Commentary” (PhD diss., Ohio State University, 1985), 154.

${ }^{5}$ Boris Vladimirovich Asafyev, Die musikalische Form als Prozess, ed. Dieter Lehmann and Eberhard Lippold, trans. Ernst Kuhn (Berlin: Verlag Neue Musik, 1976). The only other Asafyev book published in German translation at the time was Igor Glebow (aka Boris Asafyev), Tschaikowskys “Eugen Onegin”: Versuch einer Analyse des Stils und der musikalischen Dramaturgie (Chaikovsky's Eugene Onegin: Attempt at an Analysis of the Style and the Musical Dramaturgy), trans. Guido Waldmann (Potsdam: Athenaion, 1949).

${ }^{6}$ An increasing number of German scholars would learn Russian over the course of the 1950s and 1960s. Nonetheless, most scholars cited Asafyev exegeses rather than any of Asafyev's own texts.
} 
idea in its East German context. ${ }^{7}$ Even the fact that East Germans initially engaged with translated Russian and Eastern European texts about Asafyev to develop their version of the theory does not lessen that theory's legitimacy. Instead I would posit that this slide from author to author is a particularly slow and clear example of a process that distinguishes translation more generally: in Suzanne Levine's phrasing, "[s]omething is destroyed-the form of the original-but meaning is reproduced through another form. A translation in this light becomes a continuation of the original, which always alters the reality it intends to create." ${ }^{8}$ The way to understand this translated idea, then, is not (only) in comparison to its first form, but rather as it functioned in East German musical life.

Recent scholarship has documented the fact that socialist nations adopted aesthetic philosophies and policies that would affirm nineteenth-century styles as being particularly suitable to the new society, explaining the intellectual maneuvers that supported an understanding of music from a past, "bourgeois" time as being nonetheless "progressive." In the East German case, a Lukácsian historiography was used to emphasize a continuity between the present and the "forward-looking" music of the past, thereby justifying traditional musical tastes. ${ }^{10}$ The extent of these intellectual maneuvers shows that continuity requires work to be maintained. And yet aesthetic policies and philosophies, for all that they are the most visible traces of a musical culture, were not the only ways that work that was done to ensure that musical tastes remained largely constant. A focus on intonatsiya shows not only that this philosophical shift happened, but also how it was made to stick: it highlights the bottom-up processes by which children and their teachers learned to hear familiar sounds as both German and progressive, traditional and socialist.

It is common in current English-language scholarship to use a transliteration of the Russian word intonatsiya instead of the English cognate intonation. East German scholars, on the other hand, used the German Intonation, a word which, prior to its association with Asafyev, referred both (as it does in English) to speech intonation and to playing in, or out of, tune. Because this article is about the unique meaning this term came to have in the GDR, I will use the Russian word intonatsiya when talking about how that theory was written about in (largely) translated scholarly discourse (which consisted of an exchange between German, Russian, Czech, and Polish scholars), and the German word Intonation when referring to what the term came to mean in East German practice.

\section{From Intonatsiya to Intonation}

Asafyev's ideas are famously difficult to parse. As the Czech musicologist Jaroslav Jiránek put it,

\footnotetext{
${ }^{7}$ See Brian James Baer and Susanna Witt, "Introduction," in Translation in Russian Contexts: Culture, Politics, Identity, ed. Brian James Baer and Susanna Witt (New York: Routledge, 2018), 1-16, https://doi.org/10.4324/9781315305356, and Lydia H. Liu, ed., Tokens of Exchange: The Problem of Translation in Global Circulations (Durham, NC: Duke University Press, 1999), https://doi.org/10.1215/9780822381129.

${ }^{8}$ Suzanne Jill Levine, The Subversive Scribe: Translating Latin American Fiction (Champaign, IL: Dalkey Archive Press, 2009), 7-8.

${ }^{9}$ See, for instance, Pauline Fairclough, Classics for the Masses: Shaping Soviet Musical Identity under Lenin and Stalin (New Haven, CT: Yale University Press, 2016), https://doi.org/10.12987/yale/9780300217193.001.0001; Kelly, Composing the Canon in the German Democratic Republic.

${ }^{10}$ Kelly, "Introduction," in Composing the Canon in the German Democratic Republic.
} 
he who seeks a conclusive definition of the term 'intonatsiya' in Asafyev will be disappointed. It is not that the author doesn't offer a definition. Quite the contrary, there are many too many definitions ... Asafyev's theory ... is simply incomplete. It exceeded the strength of one person to map out this entire system, which is a methodological innovation aiming to encompass the entire breadth of musical law. ${ }^{11}$

Others noted the difficulties posed by Asafyev's writing, complaining that "his manner of expression is colorful, and contrived to the point of being mannered." ${ }^{12}$ Thus the scholarship that introduced intonatsiya to an East German audience was often concerned with exegesis: interpreting the premises Asafyev had laid out.

These initial exegeses, as well as the German scholarship that would use them, boiled down to several matters of concern. Chief among these was the relationship between music and language. In the early 1950s, this question had a political as well as philosophical urgency due to the 1950 publication of Josef Stalin's work Marxism and Problems of Linguistics, which sparked a flurry of discussion about the relationship between language and the arts. ${ }^{13}$ But even after the need to respond to Stalin's text had waned, scholars still concentrated most of their efforts on explicating Asafyev's central idea: was the proposed relationship between speech to be taken metaphorically or literally? How important were the observable differences between language and music (such as, for instance, the fact that language could be translated, but music could not be)? Was music directly mimetic of speech, or were both imitative of a third term, such as "movement" - in which falling vocal pitch and a falling melodic line both referred to a sinking feeling, such as that caused by disappointment? Was the relationship current, or only historical—had speech and music started out twinned and then grown apart?

It was musical intonatsiya's relationship to speech that gave music its expressive power, just the way the intonation of speech lent emotional weight to spoken words. As the Russian musicologist Wiktor Wanslow (Viktor Vanslov) put it, "the 'manner' in which a musical form is created is similar to the 'manner' in which human feelings are expressed via the intonation of spoken language (high pitches, changes in pitch and in the register of the tone color, rhythm, etc.)." ${ }^{14} \mathrm{He}$ continued, "it is exactly through this actually existing analogy between the essence-the nature-of musical language and the intonation of the spoken word that the term 'musical intonatsiya' in the narrower sense has developed: that which describes a melodic turn (motive, a variation on a melody) with a certain expressivity." 15

Wanslow's use of the term "analogy" was apt: all scholars agreed that the two terms were alike, but not identical. There were some key differences between music and language. For one, as Stalin had established, language was part of the base, whereas music was part of the superstructure. Moreover, according to Stalin, they had different functions: language enabled communication whereas music did not. Language served all classes equally; music was a form of ideology and had historically been used as

\footnotetext{
${ }^{11}$ Jaroslav Jiránek, "Zu einigen Grundbegriffen der marxistischen Ästhetik” [Concerning Some Basic Terms of Marxist Aesthetics], Beiträge zur Musikwissenschaft 5, no. 4 (1963): 264.

${ }^{12}$ Lothar Hoffmann-Ebrecht, "B. W. Assafjew-Glebow," Musik und Gesellschaft 2, no. 7 (1952): 214.

${ }^{13}$ Iosif Stalin, Marksizm i voprosi yazïkoznaniya (Moscow: Gosudarstvennoye izdadel'stvo politicheskoy literaturi, 1950). See also Joseph Stalin, Marxism and Problems of Linguistics (New York: Prism Key Press, 2013).

${ }^{14}$ Wiktor Wladimirowitsch Wanslow, “Über die Intonation,” trans. Eichhorn, Musik und Gesellschaft 3, no. 7 (1953): 254 8. In this essay, all Russian names will be given in their German transliterations.

${ }^{15}$ Ibid., 255.
} 
part of class-based oppression. ${ }^{16}$ But from there, opinions about the relationship between music and language diverged. To some, such as the Soviet musicologist Juli Kremljow (Yuliy Kremlyov), nearly all musical intonatsiyas were mimetic: they were the "intonatsiyas of human speech put into musical form." (Those few intonatsiyas that were not imitations of language were imitations of nature and of daily life. ${ }^{17}$ Kremljow, however, cautioned against using this connection between music and language to attempt to translate music into words, as if one could hear a text shadowing each melody: it was not denotative meanings or specific words that were imitated in musical intonatsiyas, but rather the sonically expressive elements of speech. For others, this was too literal and "one-sided" a solution for a complex issue. ${ }^{18}$ Viewing musical intonatsiya as a pale imitation of speech-instead of as an expressive medium in its own right-was the sort of anti-dialectical thinking that marked bourgeois historiography. ${ }^{19}$ Instead, Wanslow and the Polish musicologist Zofia Lissa proposed that music and language were similar because both were sonic reflections of human emotion. ${ }^{20}$

Thus the exact nature of the relationship that intonatsiya posed between music and speech was vexed. But the analogy's very existence-the fact of the relationship itself-was often invoked to verify other truths about intonatsiya: as Wanslow put it, "that real analogy that exists between the intonatsiya of the spoken word and of the musical language is significant for numerous other musical phenomena." ${ }^{21}$ First among these, of course, was music's vaunted ability to communicate content. But no less important was intonatsiya's "national cast" ${ }^{22}$ : like language, it was unique to each nation, and, acting as a kind of national "vocabulary," it vouchsafed a common style among composers. ${ }^{23}$ As the German musicologist and professor of pedagogy Walther Siegmund-Schultze wrote, "despite the stylistic variance among [Bach, Mozart, and Beethoven], their melodic language still adheres to something shared which stamps them as German masters." What was more, this Intonation offered

\footnotetext{
${ }^{16}$ J[uli Anatoljevitch] Kremljow, "Über einige Fragen der sowjetischen Musikwissenschaft” [On Some Questions of Soviet Musicology], Musik und Gesellschaft 2, no. 6 (1952): 184-6; Zofia Lissa, "Die Sprachintonation und die Melodik der Musik" [Speech Intonation and Musical Melody], in Fragen der Musikästhetik: einige Probleme der Musikästhetik im Lichte der Arbeit F. W. Stalins "Der Marxismus und die Frage der Sprachwissenschaft" [Questions of Musical Aesthetics: Some Problems of Musical Aesthetics with regards to J. V. Stalin's 'Marxism and Problems of Linguistics'] (Berlin: Henschelverlag, 1954), 226-9; Nathan Notowicz, "Sprache und Dialekt in der Musik" [Speech and Dialect in Music], Musik und Gesellschaft 3, no. 6 (1953): 209-11. Citations of Stalin's text largely disappeared after Stalin's death in 1953. Whereas Stalin's points about base/superstructure may have lost their relevance, the basic premise-that music and language were qualitatively different-persisted.

${ }^{17}$ Kremljow, "Über einige Fragen,” 185.

${ }^{18}$ Lissa, "Fragen der Musikästhetik," 245.

${ }^{19}$ József Ujfalussy, “Zur Dialektik des Wirklichkeitsbildes in der Musik” [On the Dialectic of the Image of Reality in Music], Beiträge zur Musikwissenschaft, no. 4 (1963): 281.

${ }^{20}$ Wanslow, "Über die Intonation," 254; Lissa, "Fragen der Musikästhetik," 239-46. Ujfalussy maintained along similar lines that language and music had previously, in the acting traditions of Mediterranean cultures, been part of a unity with bodily movement. Ujfalussy, “Zur Dialektik," 280.

${ }^{21}$ Wanslow, "Über die Intonation," 256. See also Ernst Hermann Meyer, "Die Intonation im deutschen Volkslied," in Aufsätze über Musik (Berlin: Henschelverlag, 1957), 104-68.

22 Wanslow, “Über die Intonation," 254.

${ }^{23}$ Lissa, however, was careful to reiterate that the metaphor of a "vocabulary" or "stock" [Bestand] of intonatsiyas should not be taken literally to correspond to the notion of a "vocabulary" in language, as intonatsiyas could never hold stable semantic meaning.
} 
insights into the nation's character, or "psychic individuality": ${ }^{24}$ thus, "the problem of Intonation stands in close relationship to the question of a real national consciousness." ${ }^{25}$

The essence of this national consciousness was most evident in folk music. The intonatsiyas of folk music, Lissa pointed out, were closest to the nation's soul, as it was in folk music that the characteristic speech melodies of a dialect were most faithfully preserved. Art music also used this vocabulary, but as it had historically functioned to shore up the power of the ruling elites rather than accompany the lives of common folk, its relationship to proletarian language was less apparent. ${ }^{26}$ Nonetheless, as Siegmund-Schultze maintained, every "valuable" work of art music was built upon the national Intonationen of folk music. ${ }^{27}$ Wanslow agreed, stating that the hallmark of "decadent, formalist" Western music was that it had completely let go of the intonatsiya of folk song. ${ }^{28}$ And thus the principle of intonatsiya was easily mobilized to reinforce a well-known binary opposition between folksy and proletarian on the one hand, and formalist and elite (and therefore undesirable) on the other.

Some scholars consequently looked to large-scale studies of folk music to discover the characteristic sounds of a nation. ${ }^{29}$ Writing in 1953, the East German musicologist Ernst Hermann Meyer attempted to define the German folk song via a catalogue of its Intonationen. To him, the functional harmonies of the common-practice era were foundational:

The melodies of newer German folk songs are strongly linked to harmony, which means that they are always conceptualized with regards to a tonal-harmonic relationship and obey the rules of functional harmony, even when they are sung monophonically. The strongest melodic expression of this harmonic tie is the use of the triad as thematic material. To a large degree, the major triad forms the skeleton of the German folk song. ${ }^{30}$

Meyer then proceeded to list a number of representative Intonationen, showing that, for him, the term Intonation primarily meant a commonly used interval:

The German folk song is diatonic. It uses clusters of large intervallic steps only infrequently. Wide leaps up and down within the melodic line, as are native to many Russian folk songs, are found only infrequently in German folk songs. The German folk song exhibits for the most part seconds, thirds, fourths, and fifths; intervals that exceed these are usually followed by closing material in smaller intervals, and it can be taken for granted that altered (especially diminished and augmented) intervals are very uncommon in German folk songs. An exception is the augmented fourth or diminished fifth that arises from broken chords, such as at the end of "Kommt a Vogerl geflogen" [A Bird Flies By]. Chromaticism is infrequent: it occurs as passing tones and episodically, mostly in pickups, and more than three half-tone steps never follow each other. Conspicuously frequent, in the German folk song, are pickups of a fourth. They contain the sequence dominant-

\footnotetext{
${ }^{24}$ Walther Siegmund-Schultze, “Wir klären Grundbegriffe: Was verstehen wir unter Intonation?” [Clarifying Basic

Terms: What Do We Understand by Intonatsiya?”], Musik in der Schule 4, no. 1 (1953): 20.

${ }^{25}$ Siegmund-Schultze, "Wir klären Grundbegriffe," 22.

${ }^{26}$ Lissa, "Die Sprachintonation und die Melodik der Musik," 228.

${ }^{27}$ Siegmund-Schultze, "Wir klären Grundbegriffe," 21.

${ }^{28}$ Wanslow, "Über die Intonation," 256.

${ }^{29}$ As reported in Antonín Sychra, "Zum Problemstellung unseres Seminars" [About the Topic of Our Seminar], Beiträge zur Musikwissenschaft 5, no. 4 (1963): 245-60.

${ }^{30}$ By "newer German folk songs" Meyer meant songs created from the mid-eighteenth century to 1848, a period which, though it did not extend to the present day, had for him crystallized the essence of German folk song and national spirit. Meyer, “Die Intonation im deutschen Volkslied,” 133.
} 
tonic. ... Beginnings of songs are almost always on the tonic, third or fifth, in other words, on a note of the tonic triad. ${ }^{31}$

Rhythm and meter played only a minor role in Meyer's taxonomy: his emphasis was strictly on the intervallic content of the songs. This was due to the fact that, for him, German folk songs relied on a very limited, or as he put it, "unified" set of rhythmic gestures: a few key combinations of eighth notes, quarter notes, and half notes, in which long(er) notes almost always appeared on stressed beats. Syncopations were a purely imported affair. Formally, the songs relied on periods of 2, 4, and 8 bars; these obeyed strict harmonic rules. Rhythm was so peripheral to Meyer's analysis that it made no appearance in the widely distributed version of the article that appeared in 1953 in the journal Musik und Gesellschaft, he would address it only in the later, longer version of the essay. ${ }^{32}$

In debating whether intonatsiya should refer to a discrete unit of music (a melody, motive, or even interval), or whether it was more complex (an expressive quality that a melody could possess, or a category under which specific gestures could be subsumed), most scholars had settled on the latter. ${ }^{33}$ It made no sense, Jiránek maintained, to use the term "at moments where it would be sufficient to speak only of melody, motive, or even interval." ${ }^{34}$ Nonetheless Meyer plunked solidly for Intonation as interval, a version that resembled more closely a familiar Herderian take on folk song than it did any of Asafyev's concerns. And, as Meyer's was one of the few texts to offer extensive, concrete examples of what an Intonation was-perhaps because his text was designed for a German audience still largely unfamiliar with the term, rather than being a translation of a contribution to an ongoing aesthetic debate-it was his notion, however simplistic, that would win out.

\section{Beyond Aesthetic Debates: Intonation as Pedagogy}

As Meyer was sketching a "vocabulary" of German folk song, East German teachers were seeking to reform music education to better suit what they believed to be children's natural abilities. Teachers complained that music learning frequently, and wrongly, occurred through imitation, with children repeating back songs that adults sang to them. This led to children being pushed to learn songs that were too complex. Many teachers argued instead that children's musical abilities developed according to strict biological laws. Toddlers and young children naturally produced a falling minor third, a “children's call," when speaking or singing. They had an inborn ear for pentatonic melodies and would only acquire the ability to sing and understand the major mode around age seven or eight. The principle underlying this belief was the so-called biogenetic law or recapitulation theory originally

\footnotetext{
${ }^{31}$ Ernst Hermann Meyer, "Die Intonation im deutschen Volkslied,” in Aufsätze über Musik (Berlin: Henschelverlag, 1957), 135-6. Similarly, Antonin Sychra's discussion of his "analysis of the intonatsiya" of 600 Moravian folk songs relies mostly on intervallic analysis, such as pointing out that a rising major seventh is one of the more frequent gestures. Sychra, "Zum Problemstellung unseres Seminars," 252.

${ }^{32}$ Ernst Hermann Meyer, "Zur Frage der 'Intonation“ im deutschen Volkslied," Musik und Gesellschaft 3, nos. 6 and 8 (1953): 207-9 and 282-6.

${ }^{33}$ Notions of the size and nature of an intonatsiya varied greatly, often within the same article. In articles published in East Germany, intonatsiya was used to refer to nearly anything: the prevailing mood in a piece, one of the themes of sonata form, a section of a work, a rhythmic motive.

${ }^{34}$ Jiránek, “Zu einigen Grundbegriffen der marxistischen Ästhetik,” 265. It is worth noting, however, that Tull's Asafyev gloss has the interval as "the basic unit" of intonatsiya.
} 
proposed by Ernst Haeckel, which held that children's musical development paralleled the development of the human species as a whole. This was a nineteenth-century idea and therefore not new. Nonetheless, many saw in the biogenetic law a truth that would guarantee a more effective pedagogy. ${ }^{35}$

In the early 1960s, new music-psychological research refuted this claim, arguing that children's ability to learn music developed via a reciprocal exchange between physiological and environmental factors. But although scientific knowledge and commonly-held pedagogical wisdom differed on the role of the outside world, both agreed that physiology placed definite limits: psychologists conceded that the brains of preschool-aged children were generally not able to apprehend a whole melody. They could only retain very short fragments. ${ }^{36}$ Thus both psychologists and teachers argued that children should be taught music by having them move through a scaffolded set of musical gestures keyed to their age. The ability to sing accurately and experience music's emotional content was posited to be a matter of slowly "acquiring" an additive vocabulary of gestures to be built into ever more sophisticated melodies. ${ }^{37}$ And thus this pedagogy took up in practice what Intonation promised in theory: it located music's ability to communicate in small meaningful units which, when combined, could create a varied expressive palette, much in the way that words combine into phrases. These units, then, were East German Intonationen.

The musicologist and professor of pedagogy Siegfried Bimberg adopted this principle in a new preschool songbook, Sputnik, Sputnik, kreise (Sputnik, Sputnik, orbit), intended for children aged roughly three through six. ${ }^{38}$ Together with two younger colleagues, Fritz Bachmann and Eva Smolik, Bimberg arranged four hundred songs in a carefully determined order meant to match the "systematic

\footnotetext{
${ }^{35}$ Anicia Timberlake, "The Practice and Politics of Children's Music Education in the German Democratic Republic, 1949-1976" (PhD diss., University of California, Berkeley, 2015).

${ }^{36}$ Paul Michel, Psychologische Grundlagen der Musikerziehung, vol. 2, 3 vols., Handbuch der Musikerziehung (Leipzig: Breitkopf \& Härtel, 1968), 27-30, 93-4. Michel was careful to distinguish his theories of child psychology from West German theories, which, according to him, held that children developed in the same way regardless of their environments.

${ }^{37}$ For more on East German pedagogy, see Oskar Anweiler, Schulpolitik und Schulsystem in der DDR (Opladen: Leske + Budrich, 1988), https://doi.org/10.1007/978-3-322-95525-8; Benita Blessing, The Antifascist Classroom: Denazification in Soviet-Occupied Germany, 1945-1949 (New York: Palgrave Macmillan, 2006), https://doi.org/10.1057/9780230601635; Angela Brock, "Producing the 'Socialist Personality'? Socialization, Education, and the Emergence of New Patterns of Behavior," in Power and Society in the GDR, 1961-1979: The "Normalisation of Rule"?, ed. Mary Fulbrook (New York: Berghahn Books, 2009), 220-52; Ernst Cloer, Theoretische Pädagogik in der DDR: eine Bilanzierung von aussen (Weinheim: Deutscher Studien, 1998); Bernd Fröde, Schulmusik in der Sowjetischen Besatzungszone und in der DDR bis Anfang der 1960er Fahre: zwischen fachorientierter Tradition und ideologischer Okkupation (Hannover: Institut für musikpädagogische Forschung, 2010); Eva Rieger, Schulmusikerziehung in der DDR (Frankfurt am Main: Diesterweg, 1977); John Rodden, Repainting the Little Red Schoolhouse: A History of Eastern German Education, 1945-1995 (New York: Oxford University Press, 2002); Nicole Zabel, "Zur Geschichte des Deutschen Pädagogischen Zentralinstituts der DDR. Eine institutionsgeschichtliche Studie” (PhD diss., Technische Universität Chemnitz, 2010).

${ }^{38}$ Fritz Bachmann, Eva Smolik, and Siegfried Bimberg, eds., Sputnik, Sputnik, kreise: Ein Liederbuch für die Vorschulerziehung (Leipzig: VEB Friedrich Hofmeister, 1958).
} 
development of the preschool child's musical abilities." ${ }^{39}$ Thus Sputnik presented a progressive grammar of increasingly challenging melodic features: widening intervals, more rhythmic subdivisions, a larger ambitus.

For Bachmann, Bimberg, and Smolik, as for Meyer, Intonation effectively meant "interval." The book began with intervals that signaled pentatonicism, slowly adding melodic turns that increased melodic "tension" and "release," thereby deepening the child's internal sense for the dominant-tonic relationship. (Though Bimberg had argued elsewhere that children were not biologically destined to begin with pentatonic singing, he still seemed to believe this procedure would produce the best results. $^{40}$ ) In sum, the Intonationen the child learned were to "lay the cornerstone for the entire later development of the child's singing and music-making." ${ }^{41}$ The book proposed not only a method for teaching children to sing, but also provided a key for exactly how its editors believed that the Intonationen of German music would signify: which intervals, which scale degrees, and which cadential patterns would communicate tension and release, instability and stability. And it is in this seemingly humble practice - teaching children not yet old enough to read-that Intonation's promise of musical communication was realized. ${ }^{42}$

Songs for the very youngest centered around the falling minor third of 5-3, occasionally embellished by $6 .{ }^{43}$ Presenting this interval as the most basic was in line with the biogenetically inflected belief that the falling minor third was inborn. ${ }^{44}$ This melodic type was often called the

\footnotetext{
${ }^{39}$ Sputnik was an optional guide for preschool education rather than a state-mandated songbook. Its main author, Siegfried Bimberg, was well versed in Intonation. A professor of music pedagogy at the Martin-Luther-Universität HalleWittenberg, he was one of the most visible and prolific figures in East German music pedagogy, and, along with Walther Siegmund-Schultze, was one of a small handful of professors of pedagogy who saw it as his task to bring current musicological research to the pedagogical community. He had a finger in every pedagogical pie: he wrote and edited numerous methodological primers and textbooks on topics from solfège to Orff Schulwerk to music history, published in both musicological and pedagogical journals on such as reflection theory and music psychology, and taught a large crop of music teachers throughout his decades at the Martin-Luther-Universität (one of the largest departments of music pedagogy in the country).

${ }^{37}$ Bachmann, Smolik, and Bimberg, eds., Sputnik, Sputnik, kreise, iii. Bimberg explained the selection procedure in Siegfried Bimberg, Musik im Kindergarten. (Berlin: Volk und Wissen, 1965), 23-64.

${ }^{40}$ Siegfried Bimberg, "Musik für Kinder und Jugendliche-das Kernstück der Musikerziehung," Musik und Gesellschaft 6, no. 4 (1956): 126.

${ }^{41}$ Bimberg, 126.

${ }^{42}$ The focus on intervals prompts a comparison to interval-based singing methods such as solfège. Indeed, Bimberg was an assertive advocate for solfège, promoting Richard Münnich's Jale, a movable-do system that used the hand signs of Curwen's and Glover's tonic sol-fa with new syllables deemed more suitable to the German language. Bimberg's support for solfège was based on the same principle of an expanding repertoire of intervals that underlay Sputnik. In Sputnik, however, he does not mention solfège. This may have been due to the fact that Sputnik was a song collection rather than a methodological guide; it contained information about what children should learn, but did not prescribe the methods that teachers should use. See Siegfried Bimberg, ed., Wie studiere ich ein Lied ein?: Arbeitshilfe für Laienchorleiter und Musikerzieher (Leipzig: VEB Friedrich Hofmeister, 1953) and Timberlake, “The Practice and Politics of Children's Music Education."

${ }^{43}$ I use integers for the pitches of the scale so that the words "dominant" and "tonic" can refer exclusively to harmony, not to scale degrees.

${ }^{44}$ The idea that this call was "natural" was widespread in the GDR. Bimberg himself actually refuted this claim at other moments, but he nonetheless began his method with a falling third. Bimberg, "Musik für Kinder und Jugendliche" and Wie studiere ich ein Lied ein?
} 
"endless melody" pattern because, as it was limited to the scale degrees 3, 5, and 6, the melody never fully came to rest on the tonic. ${ }^{45}$

After a child had mastered the falling third, her pitch vocabulary was expanded to include scale degrees 2 and 4 . This second group constituted the first real lesson in functional harmony. The central melodic gesture of this stage was a stepwise descending scale from 5 to 1 , which would provide a release of "tension" and offer the first "hints of the dominant-tonic relationship." All of the other melodic turns in this group of songs reinforced these features: phrases tended to end on the notes of the tonic triad, and leaps of a third were common, often descending towards 1 . Finally, the use of the scale degree 6 on a strong beat, rather than merely as a neighbor tone, added a new sort of melodic tension unlike that produced by the pitches of the dominant chord. Songs of these two types were easily mastered by the preschool's youngest pupils, aged 3 to 4 .

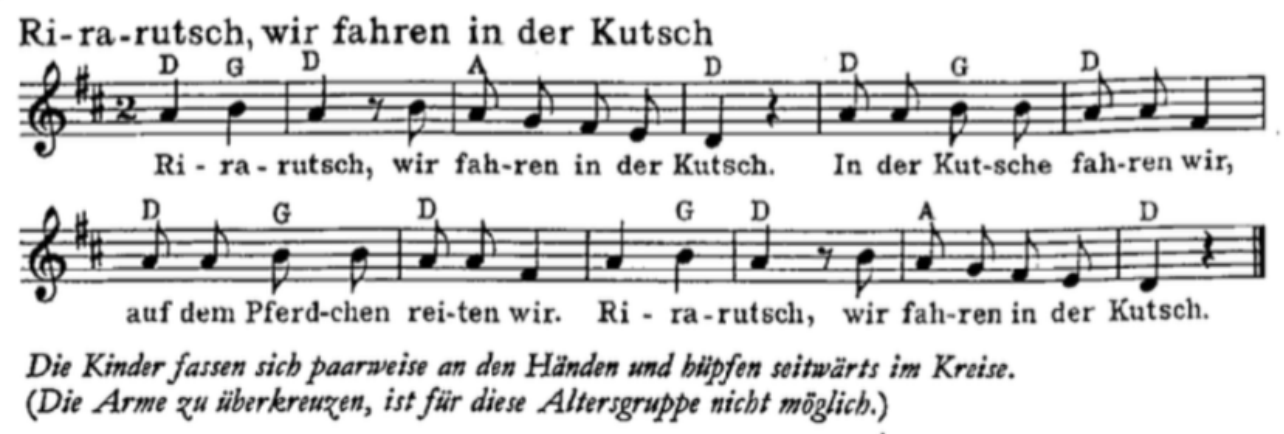

Figure 1: A typical song of melodic group 2. Sputnik, Sputnik, kreise, 4. Text: Ri-ra-rutsch, we are riding in the carriage. / In the carriage we ride, on the horse we ride. / Ri-ra-rutsch, we are riding in the carriage. Directions: The children hold hands in pairs and hop sideways in a circle. Crossing the arms is not possible for this age group.

The third group's songs solidified the magnetic pull of the tonic. The melodies of this group featured aspects that were meant to increase melodic tension, such as ascending scales and pitches of the dominant triad that fell on strong beats. Rising triadic patterns were to strengthen both the tonic and the singer's awareness of the tonic-dominant relationship. These melodies also made frequent use of sequential motion.

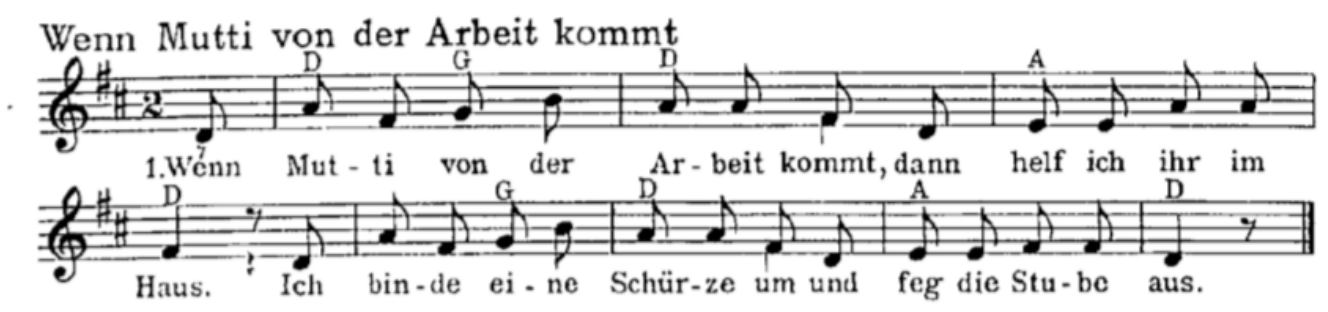

Figure 2: A song from Group 3. Sputnik, Sputnik, kreise, 85. Text: 1. When Mommy comes from work, I help her in the house. / I put on my apron and sweep out the room.

\footnotetext{
${ }^{45}$ This is similar to some regional variants of the Anglophone nursery rhymes "A tisket, a tasket" and "Ring around the rosy."

${ }^{46}$ Bachmann, Smolik, and Bimberg, Sputnik, Sputnik, kreise, 182.
} 


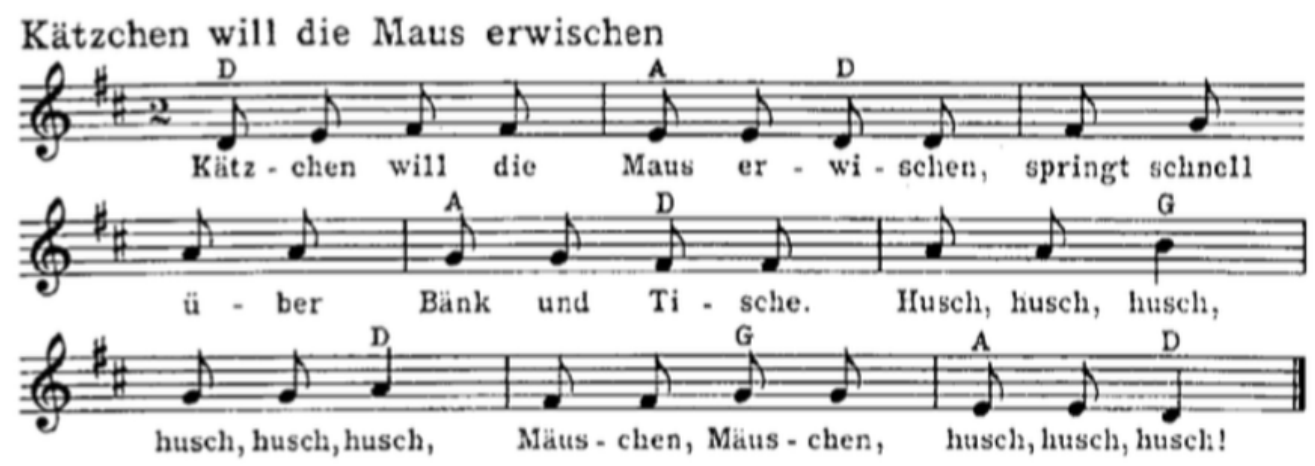

Figure 3: A song from Group 3. Note the sequences in both halves of the song. Sputnik, Sputnik, kreise, 65. Text: The kitty wants to catch the mouse, it leaps quickly over benches and tables. / Hurry, hurry, hurry, hurry, hurry, hurry, mousie, mousie, hurry, hurry, hurry!

The fourth step was to expand the melodies' harmonic range, making more substantive use of both subdominant and dominant implied harmony (Figure 4). ${ }^{47}$ Some melodies featured entire measures harmonized with the subdominant. Phrases were now permitted to end on the dominant. Bimberg explained that the songs in these two groups would be appropriate for children in the middle of their preschool education, aged 4 to 5 .

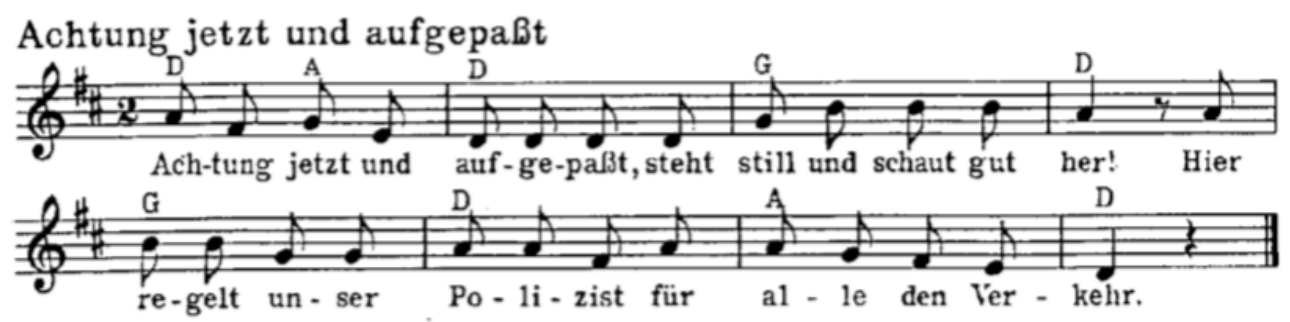

Figure 4: A song from Group 4. Note that measure 3 is harmonized with the subdominant. Sputnik, Sputnik, kreise, 11. Text: Now pay attention and listen carefully, stand still and look over here! Here our policeman is directing traffic for everyone.

The final three groups, intended for the oldest children (ages 5 and 6), expanded the songs' ranges and completed the sense for tonic-dominant polarity. The melodies of group 5 used the upper half of the octave. Group 6 expanded the range from the lower scale degree 5 to the upper supertonic. These songs used scale degree 5 as an anacrusis and, finally, adopted the lower leading tone to prepare a cadence. They offered a wider palette of melodic gestures, allowing for the use of arpeggiated dominant seventh chords and leaps of fourths, fifths, and sixths in addition to the (by then well-known) thirds. These groups also introduced new rhythmic and metrical features to a repertoire previously characterized by duple meter and constant melodic motion: triple meter, three-measure phrases, rests, and even the alternation of triplet and duplet subdivisions of a beat.

\footnotetext{
${ }^{47}$ The "harmony" the authors discussed referred to the harmonic functions implied by the melodies: the melodies were designed to inculcate children into the logic of functional harmony even without the assistance of other pitches of the chord.
} 
Liebe Schwester, tanz mit mir
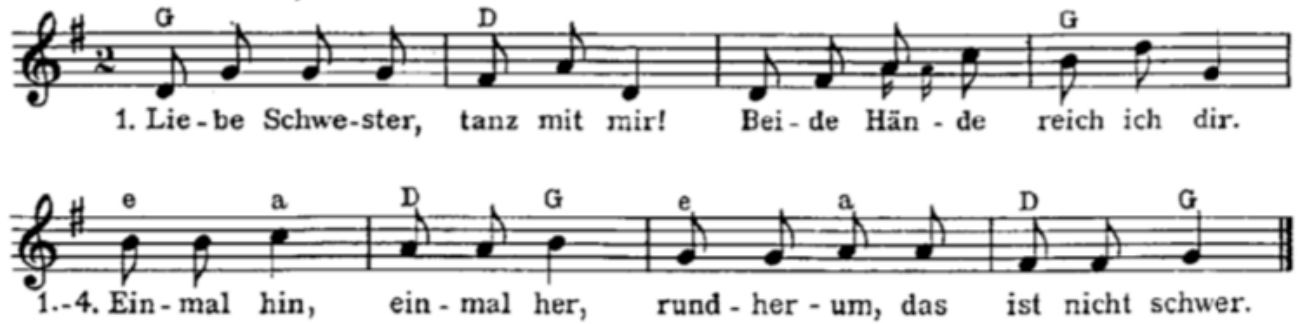

Figure 5: Song from Group 6. Sputnik, Sputnik, kreise, 56. Text: Dear sister, dance with me! I offer you both my hands. Once here, once there, turn around, it isn't hard.

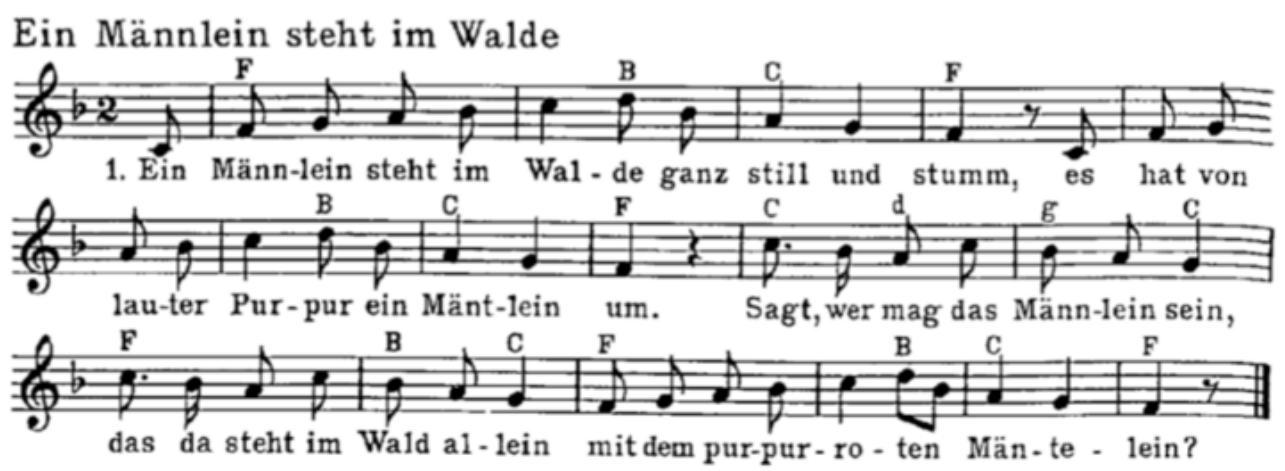

Figure 6: Song from Group 6. Sputnik, Sputnik, kreise, 80. Text: A man stands in the woods so silently, he wears a purple cloak. Say, who is that man, who stands alone in the woods with a purple-red cloak?

With those steps, the work was mostly done. With the completion of the sixth group, children had internalized the logic of common-practice tonal music, and had developed the skills to sing a number of beloved children's songs, such as "Ein Männlein steht im Walde" and "Liebe Schwester, tanz mit mir" (Figures 5 and 6). The seventh group introduced shifting meters (as were common in some Bavarian and Swabian folk songs; Figure 7), modulations in the middle section of ABA songs, and minor keys. But as this group was tacked on as a seeming afterthought (it contained only nineteen songs, in contrast to the ca. eighty songs each of groups 5 and 6), the Intonationen it presented may have been thought less essential. 
Der Spielmann, der Spielmann ist immer noch nicht da

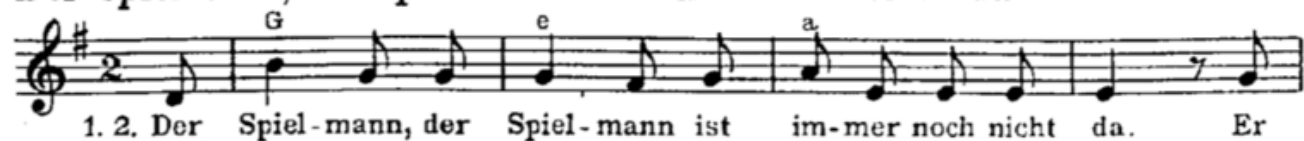

1. 2. Der Spiel-mann, der Spiel-mann ist im-mer noch nicht da. Er
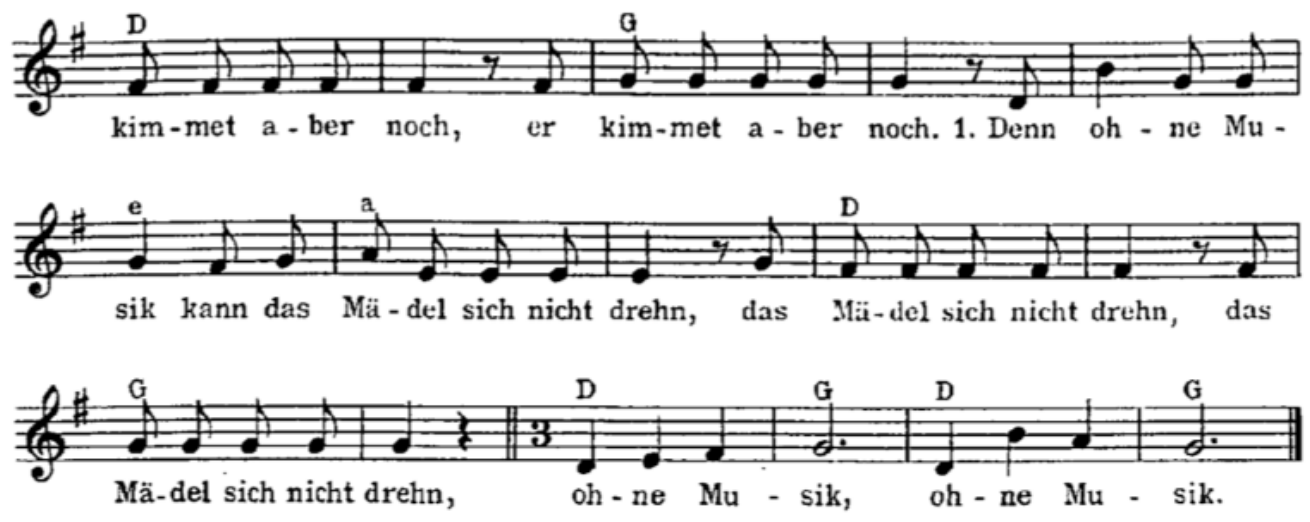

Figure 7: A song from Group 7. Note the metrical shift in the sixteenth measure. Sputnik, Sputnik, kreise, 56. Text: The bandsman, the bandsman is still not here. He's still coming, he's still coming. For without music the girls can't spin, the girls can't spin, the girls can't spin, without music, without music.

\section{German Nature}

Sputnik's lessons provide a catalogue of the Intonationen that were believed to form the backbone of the tonal German musical language. The editors took pains to lay out exactly the properties of each: without the grounding presence of 1 , the minor third between scale degrees 5 and 3 would "float" endlessly. Descending stepwise motion to 1 resolved melodic tension, but elements like spelled-out tonic chords, the lower leading tone, and 5 used as an anacrusis would truly solidify a sense of the tonic, and with it a sense of rest. On the other hand, pitches of the dominant chord on a strong beat would increase tension, as would larger melodic leaps; pitches that implied the subdominant, however, would produce a different sort of tension. Melodic sequences would continue a mood; parallel phrase structures to open and close the song would produce an even more satisfying close. This was the communicative power of tonal music: it was able to convey experiences of tension and resolution that could be creatively extended, delayed, and otherwise reinforced.

Even more significantly, these Intonationen were arranged in a series of steps that tracked the child's developing physiology. Just as children's performance capabilities were determined by age, teachers maintained that children's ability to access the emotional depth of music changed as they grew. Young children were concerned with "outer" aspects of music (such as tempo) and with puberty became aware that music contained an interior dimension. It was only with full maturity that young adults developed an adequate appreciation for the emotional subtlety of the music of the seventeenth and eighteenth centuries, music that for East German educators exemplified the pinnacle of the tonal 
tradition. ${ }^{48}$ Sputnik's progression from an "endless" pentatonic to melodies in which the "polarity" between tonic and dominant has been maximized also showed a journey of maturation in miniature, growing from a naive "children's call" to the beginning of a complex system of expression. Thus, as the book worked in concert with the child's developing musical skill, it also helped its young singers acquire the Intonationen that would later allow them to appreciate emotionally complex music, reinforcing the idea that emotional depth and tonic-dominant tension went hand-in-hand. ${ }^{49}$

For all that, the songs included in Sputnikwere remarkably homogenous, both in terms of music and also in terms of textual content. This may be no surprise: they were training songs. This fact explains not only the expanding palette of intervals, but also the near-exclusive use of the key of D in the first four groups (this corresponded to the narrow range of children's voices) and the preponderance of songs about animals, the seasons, play, and trains (this was believed appropriate for children's predisposition towards the natural world and towards repetitive motion). In fact, despite the book's title, only a handful of songs address themes that could be seen as relating to twentieth-century life specifically: the construction of new buildings, machines such as cranes and tractors, and how to assist Mother as she leaves for her workday. A scant six songs address themes specific to the GDR: three about Sputnik and three about the May 1 holiday.

Thus the songs are limited by the abilities of their target audience and are by no means intended to represent the full spectrum of German music. And yet the melodic, rhythmic, and formal patterns for which the songs were selected match precisely Meyer's own descriptions of the characteristic Intonationen of the German folk song. The songs in Sputnik were exclusively diatonic and nearly always major-folks songs were "always conceptualized with reference to a tonal-harmonic relationship," and relied heavily on the pitches of the major triad. ${ }^{50}$ The most advanced children's songs had an ambitus of at most an eleventh (according to Meyer: "the ambitus of the German folk song is generally not very large. The range of an octave plus a fourth is rarely reached"), ${ }^{51}$ used an upbeat of a fourth (according to Meyer, these were "conspicuously frequent" in folk songs), and used cadential formulae such as (5-4) 3-2-1, 2-5-1, and 2-7-1 (according to Meyer, the "importance" of cadential formulae that reinforced the major mode were "not to be underestimated"). ${ }^{52}$

The similarity between Meyer's work and this pedagogical text signals that a close, dependent relationship was actively being cultivated between children's music and "folk" traditions. In East Germany, in lingering Romantic fashion, children were believed closer to pure, "original" man than adults, who had been sullied by civilization. The fact that children's music education was designed scientifically to match their naturally-determined and unalterable musical capabilities implied that music suitable for them was the most "natural." Therefore, the musical similarities between simple songs for children and "true" German folk songs also reinforced the innate "naturalness" of German song.

\footnotetext{
${ }^{48}$ Paul Michel, Musik und Hörer in unserer Zeit: psychologische und pädagogisch-methodische Grundfragen der Musikverbreitung im Deutschen Kulturbund (Berlin: Deutscher Kulturbund, 1967); Wissenschaftliche Zeitschrift der Martin-Luther-Universität Halle-Wittenberg, Gesellschafts- und sprachwissenschaftliche Reihe vol. 10 no. 1, February 1961.

${ }^{49}$ For more on children's physiological and emotional development, see the essays in the Wissenschaftliche Zeitschrift der Martin-Luther-Universität Halle-Wittenberg, Gesellschafts- und sprachwissenschaftliche Reihe vol. 10 no. 1, February 1961.

${ }^{50}$ Meyer, "Die Intonation im deutschen Volkslied," 133.

${ }^{51}$ Ibid., 140.

52 Ibid.
} 
However, nature itself also had a distinctly German character. After all, Meyer had written, "from all folk songs of the world, genuineness, warmth, and noble, strong simplicity streams to us. But the intellectual and emotional content of the German folk song is nonetheless different from the song of other peoples. In it, the specific nature of the national psychic character of the German people expresses itself." The particular simplicity was unique, Meyer explained, as "the essence of the German folk song is not ornamental like Oriental, Romanian, Spanish and other folk songs, but motivic." Nonetheless, "even with its straightforwardness it is not primitive, but plastic." And, unlike French folk songs and Irish and Scottish reels, it avoided repetition; even though repetition existed "occasionally" in children's songs-and here Meyer, for the only time, drew a distinction between children's and folk songsGerman songs were based instead on melodic sequences, a device which was only occasionally present in the Sputnik songs. ${ }^{53}$

Meyer's characterization of German folk songs, as he himself proclaimed, was also a description of German character: nobly plain rather than frivolously decorated; thoughtfully varied rather than mindlessly repetitive; organic rather than artificial (for the "motivicism" he touted was part of a long German intellectual tradition of finding aesthetic value in artistic unity, and seeing that unity as the proof of a work's proximity to nature).$^{54}$ And therefore the progressive grammar of children's songs laid out in Sputnik acquires a nationalist cast. Understood as the typical Intonationen of German song, the songs both make an argument for the natural simplicity of German music and also present as naturaland as uniquely German - the basic logic of a nineteenth-century understanding of diatonic music, in which the polarity of tonic and dominant is the most salient feature. Thus the natural Intonation of German folk song seemed to be identical with the principles of common-practice music-and the familiar notion of German music being universal and unmarked was revisited once again.

\section{Epilogue}

In 1976, a German translation of Musical Form as Process was published. ${ }^{55}$ In the preface to this volume, editors Dieter Lehmann and Eberhard Lippold set out to correct some common misunderstandings about intonatsiya. It was not true that individual intervals maintained stable meanings across musical works: in other words, a horn call was not always a horn call. One was not to "dissolve" intonatsiya into a collection of semantic meanings-in other words, to attempt to approximate a dictionary. Also incorrect was restricting intonatsiya to national musical characteristics: though Asafyev did admit the nation's significance for music's development, it was by no means the only important factor. These reductive ideas missed the mark, Lehmann and Lippold argued, because the brilliance of Asafyev's theory was its high degree of "(dialectical) generality": it was this quality that granted intonatsiya its near-universal validity. ${ }^{56}$

What Lehmann and Lippold were critiquing, of course, was exactly what intonatsiya had come to

\footnotetext{
${ }^{53}$ Ibid., 137.

${ }^{54}$ Mark Evan Bonds, Music as Thought: Listening to the Symphony in the Age of Beethoven (Princeton, NJ: Princeton University Press, 2006), 55-7; Holly Watkins, "From the Mine to the Shrine: The Critical Origins of Musical Depth," Nineteenth-Century Music 27, no. 3 (2004): 179-207, https://doi.org/10.1525/ncm.2004.27.3.179.

${ }_{55}^{5}$ Asafyev, Die musikalische Form als Prozess.

${ }^{56}$ Ibid., 18.
} 
mean in the GDR. They were correct in that the ways in which the notion was understood and put to use were not the same as what Asafyev had proposed. However, the fact that subtleties were lost in a game of academic telephone is less significant to the historian than what came out on the other end. On the one hand, as I have shown, the concept of Intonation in East Germany was ultimately mobilized in order to support a continuity with the past-with a particularly nostalgic idea of a simpler time. As such, it was of a piece with other efforts to link the socialist present with the Romantic cultural past. On the other hand, Intonation also supported East German teachers in achieving one of their goals: a more egalitarian music education. One of the founding principles of East German music pedagogy was to increase access to an aesthetic education. This project had a particular political urgency in the immediate post-Nazi period, as many worried that mystical, "anti-worldly" attitudes towards music had not only reinforced elitism but also contributed to fascism. The promise of Intonation was not that it offered new insights into music - it presented only the most basic tenets of functional harmony-but rather that it took literally the idea that music was a kind of language, a meaningful and learnable system. Sputnik would lay out, in simple, step-by-step form, how to hear music in terms of large-scale patterns of tension and release.

Indeed, it is remarkable how seamlessly intonatsiya became Intonation: how the idea, simplified as it may have been, moved from a Russian to a German context, and how well it took root in Germany, a rootedness demonstrated by its easy assumption into pedagogical practice. This goes to show not that Soviet-sanctioned ideas were successful in "occupying” East German schools-as some pedagogical historians have argued—and more that Asafyev's ideas resonated with musicological and pedagogical concerns of long standing in German musical life. ${ }^{57}$ As Olga Panteleeva has demonstrated, Asafyev himself, and late Imperial/early Soviet scholarship more generally, was in productive dialogue with nineteenth-century continental intellectual thought. ${ }^{58}$ Thus Meyer's Herderian Intonation and the pedagogical impulses with which it resonated did not represent a resistance to Asafyev's ideas: what transpired in East German musical life, instead, was a family reunion.

\section{Bibliography}

Anweiler, Oskar. Schulpolitik und Schulsystem in der DDR. Opladen: Leske + Budrich, 1988. https://doi.org/10.1007/978-3-322-95525-8.

Asafyev, Boris V. Tschaikowskys "Eugen Onegin": Versuch einer Analyse des Stils und der musikalischen Dramaturgie. Translated by Guido Waldmann. Potsdam: Athenaion, 1949.

—. Die musikalische Form als Prozess. Edited by Dieter Lehmann and Eberhard Lippold. Translated by Ernst Kuhn. Berlin: Verlag Neue Musik, 1976.

Bachmann, Fritz, Eva Smolik, and Siegfried Bimberg, eds. Sputnik, Sputnik, kreise: Ein Liederbuch für die Vorschulerziehung. Leipzig: VEB Friedrich Hofmeister, 1972.

\footnotetext{
${ }^{57}$ See, for instance, Anweiler, Schulpolitik und Schulsystem in der DDR, and Fröde, Schulmusik.

${ }^{58}$ Olga Panteleeva, "How Soviet Musicology Became Marxist," Slavonic E East European Review 97, no. 1 (2019): 73-109, https://doi.org/10.5699/slaveasteurorev2.97.1.0073; Olga Panteleeva, "Formation of Russian Musicology from Sacchetti to Asafyev, 1885-1931" (PhD diss., University of California, Berkeley, 2015). Tull also points to the fact that Asafyev was more influenced by Hegel than by Marx. Tull and Asaf'ev, Musical Form as a Process, 142.
} 
Baer, Brian James, and Susanna Witt, eds. Translation in Russian Contexts: Culture, Politics, Identity. New York: Routledge, 2018. https://doi.org/10.4324/9781315305356.

Bimberg, Siegfried. "Musik für Kinder und Jugendliche—das Kernstück der Musikerziehung.” Musik und Gesellschaft 6, no. 4 (1956): 126-28.

-. Musik im Kindergarten. Berlin: Volk und Wissen, 1965. . Nachhall: 44 Jahre Schulmusik nach Marx und Lenin. Reflexionen zur Musikpädagogik in der DDR. 2 vols. Essen: Verlag Die Blaue Eule, 1996.

—, ed. Wie studiere ich ein Lied ein?: Arbeitshilfe für Laienchorleiter und Musikerzieher. Leipzig: VEB Friedrich Hofmeister, 1953.

Blessing, Benita. The Antifascist Classroom: Denazification in Soviet-Occupied Germany, 1945-1949. New York: Palgrave Macmillan, 2006. https://doi.org/10.1057/9780230601635.

Bonds, Mark Evan. Music as Thought: Listening to the Symphony in the Age of Beethoven. Princeton, NJ: Princeton University Press, 2006.

Brock, Angela. "Producing the 'Socialist Personality'? Socialization, Education, and the Emergence of New Patterns of Behavior." In Power and Society in the GDR, 1961-1979: The "Normalisation of Rule"?, edited by Mary Fulbrook, 220-52. New York: Berghahn Books, 2009.

Brown, Malcolm H. "The Soviet Russian Concepts of 'Intonazia' and 'Musical Imagery.” The Musical Quarterly60, no. 4 (1974): 557-67. https://doi.org/10.1093/mq/LX.4.557.

Cloer, Ernst. Theoretische Pädagogik in der DDR: eine Bilanzierung von aussen. Weinheim: Deutscher Studien, 1998.

Fairclough, Pauline. Classics for the Masses: Shaping Soviet Musical Identity under Lenin and Stalin. New Haven, CT: Yale University Press, 2016. https://doi.org/10.12987/yale/9780300217193.001.0001.

Frackman, Kyle, and Larson Powell, eds. Classical Music in the German Democratic Republic. Production and Reception. Woodbridge, UK: Boydell \& Brewer Ltd., 2015.

Fröde, Bernd. Schulmusik in der Sowjetischen Besatzungszone und in der DDR bis Anfang der 1960er Jahre: zwischen fachorientierter Tradition und ideologischer Okkupation. Hannover: Institut für musikpädagogische Forschung, 2010.

Frolova-Walker, Marina. Music and Soviet Power, 1917-1932. Woodbridge, UK: Boydell and Brewer, 2017.

Gelbart, Matthew. The Invention of "Folk Music" and "Art Music": Emerging Categories from Ossian to Wagner. Cambridge: Cambridge University Press, 2007. https://doi.org/10.1017/CBO9780511481918.

Herder, Johann Gottfried, and Bohlman, Philip. Song Loves the Masses: Herder on Music and Nationalism. Oakland: University of California Press, 2017. https://doi.org/10.1525/california/9780520234949.001.0001.

Hoffmann-Ebrecht, Lothar. "B. W. Assafjew-Glebow.” Musik und Gesellschaft 2, no. 7 (1952): 21315.

Jiránek, Jaroslav. “Zu einigen Grundbegriffen der marxistischen Ästhetik.” Beiträge zur Musikwissenschaft 5, no. 4 (1963): 261-74. 
Kelly, Elaine. Composing the Canon in the German Democratic Republic: Narratives of NineteenthCentury Music. New York: Oxford University Press, 2014. https://doi.org/10.1093/acprof:oso/9780199998098.001.0001.

Kelly, Elaine, and Amy Wlodarski. Art Outside the Lines: New Perspectives on GDR Art Culture. New York: Rodopi, 2011. https://doi.org/10.1163/9789401200400.

Knepler, Georg. “Zur Frage der Widerspiegelung der Wirklichkeit in Beethovens Musik.” Musik und Gesellschaft 2, no. 3 (1952): 66-71.

Kremljow, J[uli Anatoljevitch]. “Über Die Intonationsvielfalt Musikalischer Gestaltung.” Musik Und Gesellschaft3, no. 4 (1953): 174.

. "Über einige Fragen der sowjetischen Musikwissenschaft." Musik und Gesellschaft 2, no. 6 (1952): 184-86.

Levine, Suzanne Jill. The Subversive Scribe: Translating Latin American Fiction. Champaign, IL: Dalkey Archive Press, 2009.

Lissa, Zofia. "Der Begriff der Intonation in der sowjetischen Ästhetik.” In Fragen der Musikästhetik: einige Probleme der Musikästhetik im Lichte der Arbeit J. W. Stalins "Der Marxismus und die Frage der Sprachwissenschaft."Berlin: Henschelverlag, 1954.

- "Die Sprachintonation und die Melodik der Musik." In Fragen der Musikästhetik: einige Probleme der Musikästhetik im Lichte der Arbeit J. W. Stalins "Der Marxismus und die Frage der Sprachwissenschaft,"219-30. Berlin: Henschelverlag, 1954.

—. Fragen der Musikästhetik: einige Probleme der Musikästhetik im Lichte der Arbeit J. W. Stalins "Der Marxismus und die Frage der Sprachwissenschaft.”Berlin: Henschelverlag, 1954.

—. Über das Spezifische der Musik. Berlin: Henschelverlag, 1957.

Liu, Lydia H. Tokens of Exchange: The Problem of Translation in Global Circulations. Durham, NC: Duke University Press, 1999. https://doi.org/10.1215/9780822381129.

McQuere, Gordon D. Russian Theoretical Thought in Music. Rochester, NY: University of Rochester Press, 2009.

Meyer, Ernst Hermann. “Die Intonation im deutschen Volkslied.” In Aufsätze über Musik, 104-68. Berlin: Henschelverlag, 1957.

—. Musik im Zeitgeschehen. Berlin: Henschel, 1952.

. "Zur Frage der 'Intonation' im deutschen Volkslied." Musik und Gesellschaft 3, no. 6 and 8 (1953): 207-9 and 282-6.

Michel, Paul. Musik und Hörer in unserer Zeit: psychologische und pädagogisch-methodische Grundfragen der Musikverbreitung im Deutschen Kulturbund. Berlin: Deutscher Kulturbund, 1967.

Notowicz, Nathan. "Sprache und Dialekt in der Musik." Musik und Gesellschaft 3, no. 6 (1953): 209_ 11.

Panteleeva, Olga. "Formation of Russian Musicology from Sacchetti to Asafyev, 1885-1931.” PhD diss., University of California, Berkeley, 2015.

. "How Soviet Musicology Became Marxist." Slavonic \& East European Review 97, no. 1

(2019): 73-109. https://doi.org/10.5699/slaveasteurorev2.97.1.0073. 
Probleme der Sowjetischen Musik: Eine Sammlung von Aufsätzen. Musik und Zeit VI. Halle: Mitteldeutscher Verlag, 1953.

Rieger, Eva. Schulmusikerziehung in der DDR. Frankfurt am Main: Diesterweg, 1977.

Rodden, John. Repainting the Little Red Schoolhouse: A History of Eastern German Education, 1945 1995. New York: Oxford University Press, 2002.

Siegmund-Schultze, Walther. "Wir klären Grundbegriffe: Was verstehen wir unter Intonation?” Musik in der Schule 4, no. 1 (1953): 19-22.

Silverberg, Laura. “'Monopol Der Diskussion?': Alternative Voices in the Verband Deutscher Komponisten Und Musikwissenschaftler." In Art Outside the Lines: New Perspectives on GDR Art Culture, edited by Elaine Kelly and Amy Wlodarski, 175-92. Amsterdam and New York: Rodopi, 2011. https://doi.org/10.1163/9789401200400_011.

Stalin, Joseph. Marksizm i voprosy iazykoznaniia. Moscow: Gos. Izd-vo polit. lit-ry, 1950.

—. Marxism and Problems of Linguistics. New York: Prism Key Press, 2013.

Sychra, Antonín. "Zum Problemstellung unseres Seminars.” Beiträge zur Musikwissenschaft 5, no. 4 (1963): 245-60.

Timberlake, Anicia. "The Practice and Politics of Children's Music Education in the German Democratic Republic, 1949-1976.” PhD diss., University of California, Berkeley, 2015.

Tull, James Robert, and B. V Asafev. “B.V. Asafev's Musical Form as a Process: Translation and Commentary.” PhD diss., Ohio State University, 1977.

Ujfalussy, József. “Zur Dialektik des Wirklichkeitsbildes in der Musik.” Beiträge zur Musikwissenschaft, no. 4 (1963): 275-82.

Um die Grundlagen der Musik: Diskussionsbeiträge über die Auswirkung der Arbeit J.W. Stalins "Der Marxismus und die Fragen der Sprachwissenschaft" auf die Musik. Musik und Zeit VII. Leipzig: Friedrich Hofmeister, 1954.

Viljanen, Elina. The Problem of the Modern and Tradition: Early Soviet Musical Culture and the Musicological Theory of Boris Asafiev (1884-1949). Helsinki: Acta Semiotica Fennica, 2016.

Wanslow, Wiktor Wladimirowitsch. "Über die Intonation.” Translated by Eichhorn. Musik und Gesellschaft 3, no. 7 (July 1953): 254-8.

Watkins, Holly. "From the Mine to the Shrine: The Critical Origins of Musical Depth." NineteenthCentury Music 27, no. 3 (2004): 179-207. https://doi.org/10.1525/ncm.2004.27.3.179.

Zabel, Nicole. "Zur Geschichte des Deutschen Pädagogischen Zentralinstituts der DDR. Eine institutionsgeschichtliche Studie.” PhD diss., Technische Universität, 2010. 